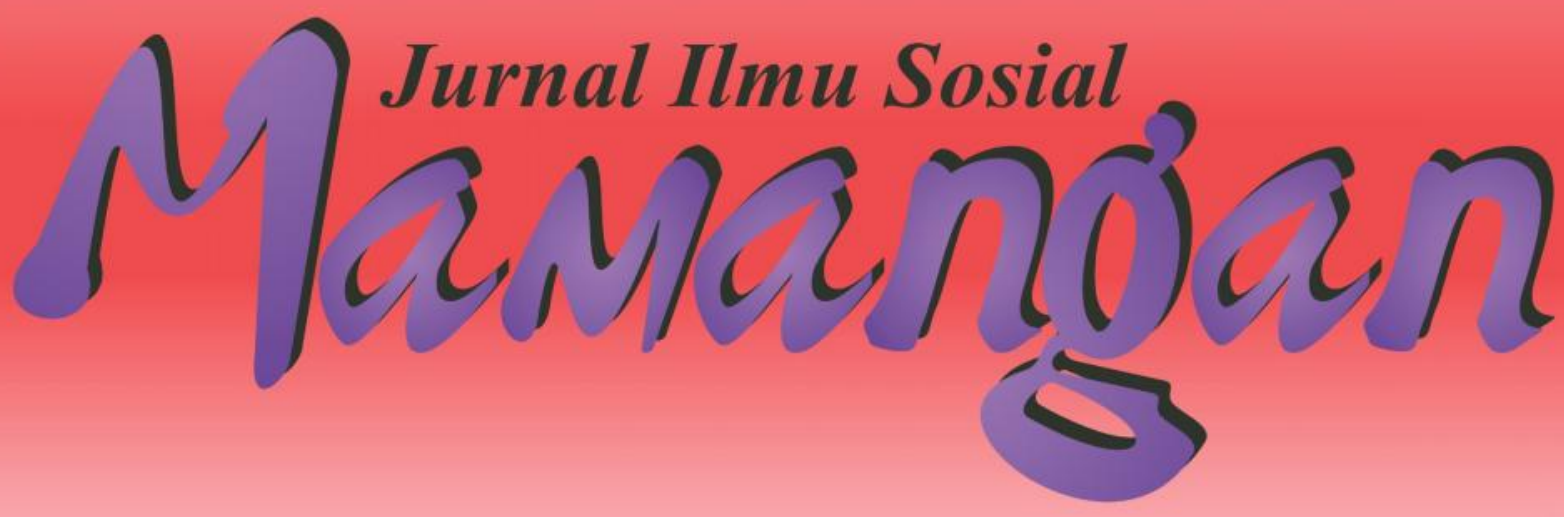

Diamika Perempuan Pedagang Makanan Di Sicincin

Elsa melia Roza, Yulkardi \& Rinel Fitlayeni

Motivasi \& Strategi Keluarga Miskin Nagari Talu, Kab. Pasaman Barat Melanjutkan Pendidikan Anak Ke Perguruan Tinggi

Cici Rahma Sari, Elvawati \& Dian Kurnia Anggreta

Dampak Sosial Ekonomi Objek Wisata The Unique Park Waterboom Di Kota Sawahlunto

Lisa Desatria, Fachrina \& Faishal Yasin

Pandangan Rumah Tangga Sasaran (RTS) Terhadap Pelaksanaan Dana Bergulir PNPM-MP Di Kelurahan Balai Gadang, Kota Padang Elparianti, ArdiAbbas \& Elvawati

Kehidupan Waria Di Jorong Mandiangin, Kecamatan Kinali, Kabupaten Pasaman Barat

Susanki \& Dian Anggraini Oktavia

Fungsi Koperasi Serba Usaha Ekonomi Desa (KSU-ED) Terhadap Masyarakat Nagari Tabek Talang Babungo, Kabupaten Solok Yenti Welia, Witrianto \& Refni Yulia 


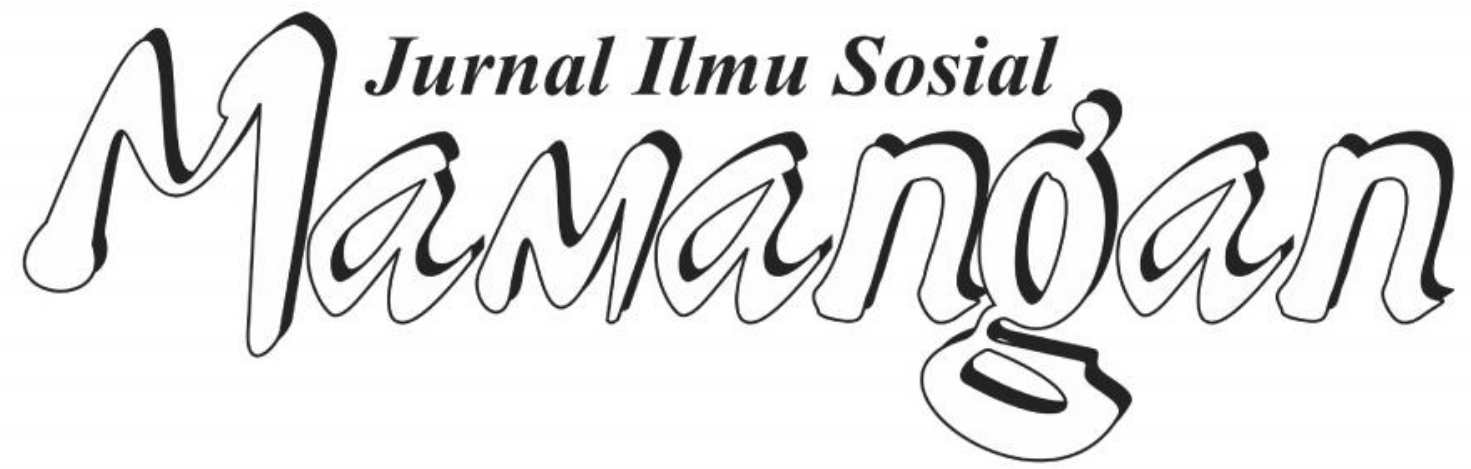




\section{Mitra Bestari}

Prof. Dr. Afrizal, MA. (FISIP, Unand Padang)

Dr. A. Latief Wiyata, M. Si. (Universitas Jember, Jember)

Prof. Dr. Badaruddin, M. Si. (FISIP, USU Medan)

Dr. Fikarwin Zuska, M. Si. (FISIP, USU Medan)

Nurus Shalihin, M. Si., Ph.D. (Fak. Ushuluddin IAIN Imam Bonjol Padang)

Dr. Semiarto A. Purwanto, M. Si. (FISIP, UI Jakarta)

Dr. Wahyu Wibowo, M. Si. (Universitas Nasional, Jakarta)

\section{Dewan Redaksi}

Dr. Zusmelia, M. Si.

Dr. Maihasni, M. Si.

Adiyalmon, S. Ag., M. Pd.

Firdaus, S. Sos., M. Si.

\section{Pemimpin Redaksi}

Firdaus, S. Sos., M. Si.

\section{Anggota Redaksi}

Dian Kurnia Anggreta, S. Sos., M. Si.

Rinel Fitlayeni, S. Sos., MA.

Surya Prahara, SH.

ISSN: 2301-8496

\section{Alamat Redaksi:}

Laboratorium Program Studi Pendidikan Sosiologi, STKIP PGRI Padang

Jl. Gunung Pangilun, Padang

Email: redaksimamangan@yahoo.com

Penerbit :

Program Studi Pendidikan Sosiologi, STKIP PGRI Padang

\section{Contac person :}

Firdaus (Hp. 085263881221/Email : daus gila@yahoo.com) 


\section{DAFTAR ISI}

Diamika Perempuan Pedagang Makanan Di Sicincin

Elsa melia Roza, Yulkardi \& Rinel Fitlayeni.

Motivasi \& Strategi Keluarga Miskin Nagari Talu, Kab. Pasaman Barat Melanjutkan Pendidikan Anak Ke Perguruan Tinggi

Cici Rahma Sari, Elvawati \& Dian Kurnia Anggreta.

Dampak Sosial Ekonomi Objek Wisata The Unique Park Waterboom Di Kota Sawahlunto

Lisa Desatria, Fachrina \& Faishal Yasin

Pandangan Rumah Tangga Sasaran (RTS) Terhadap Pelaksanaan Dana Bergulir PNPM-MP Di Kelurahan Balai Gadang, Kota Padang

Elparianti, Ardi Abbas \& Elvawati

Kehidupan Waria Di Jorong Mandiangin, Kecamatan Kinali, Kabupaten Pasaman Barat

Susanki \& Dian Anggraini Oktavia

Fungsi Koperasi Serba Usaha Ekonomi Desa (KSU-ED) Terhadap Masyarakat Nagari Tabek Talang Babungo, Kabupaten Solok 


\title{
DIAMIKA PEREMPUAN PEDAGANG MAKANAN DI SICINCIN
}

\author{
1Elsa melia Roza, ${ }^{2}$ Yulkardi \& ${ }^{3}$ Rinel Fitlayeni \\ ${ }^{1 \& 3}$ Sekolah Tinggi Keguruan dan Ilmu Pendidikan (STKIP) PGRI Sumatera Barat \\ 2 Universitas Andalas
}

\begin{abstract}
This article discusses the activities of women food vendors in Nagari Sicincin, women's involvement has keterbartasan informal sector to resources and access. As a result, business options that can be entered also ranges in some specific fields such as trade food hawkers. Women asongan food traders in carrying out its activities he had to leave the family in a period of 9-10 hours a day. Before going home or going to work, he must do homework at the same time, This article aims to describe the activities of women food vendors hawkers around Station Sicincin. and analyze the constraints experienced by women hawkers hawkers in work. The method used qualitative descriptive type, The data collection is done by observation, interview and documentation study, The findings of this article, namely the allocation of time, that work outside the home as a trader of food hawkers, conducted from 08.00 am until 17:00 pm, Competition and conflict. Tip mastery of the market situation, that take advantage of the holiday, shoppers want visited by giving discounts to buyers, already terbntuknya image salted egg and boiled bananas. and the constraints faced by women food vendors hawkers are obstacles in the work, namely the driver and passenger Bus unfriendly, and the absence of gas stations.
\end{abstract}

\section{Keywords : Woman Trader, Pattern of Trade, Infromal Sector}

\begin{abstract}
ABSTRAK
Artikel ini membahas aktifitas perempuan pedagang makanan di Nagari Sicincin, keterlibatan perempuan disektor informal memiliki keterbartasan terhadap sumber daya dan akses. Akibatnya pilihan usaha yang dapat dimasuki juga berkisar pada beberapa bidang tertentu seperti berdagang makanan asongan. Perempuan pedagang makanan asongan dalam menjalankan aktivitasnya ia harus meninggalkan keluarga dalam jangka waktu 9-10 jam dalam sehari. Sebelum pulang ataupun berangkat kerja, ia harus mengerjakan pekerjaan rumah sekaligus. Artikel ini bertujuan untuk mendeskripsiakn aktivitas perempuan pedagang mkanan asongan di sekitar Terminal Sicincin, dan menganalisis kendala-kendala yang dialami oleh prempuan pejaja makanan asongan dalam pekerjaan. Metode yang digunakan kualitatif dengan tipe penelitian deskriptif. Pengumpulan data dilakukan dengan cara observasi, wawancara, dan studi dokumentasi. Temuan dari artikel ini yaitu alokasi waktu, yaitu pekerjaan diluar rumah sebagai pedagang makanan asongan, dilakukan dari jam 08.00 WIB sampai jam 17.00 WIB. Persaingan, dan konflik. Kiat penguasaan situasi pasar, yaitu memanfaatkan hari libur, pembeli ingin didatangi memberikan potongan harga bagi pembeli, sudah terbntuknya image telur asin dan pisang jantan rebus. dan kendala-kendala yang dialami perempuan pedagang makanan asongan adalah kendala dalam pekerjaan, yaitu supir dan penumpang Bus tidak bersahabat, dan ketiadaan SPBU..
\end{abstract}

Kata Kunci: Pedagang Perempuan, Pola Dagang, Sektor Informal 


\section{PENDAHULUAN}

Dalam masyarakat tradisional umumnya status perempuan lebih rendah dari laki-laki. Kaum perempuan lebih terfokus pada kegiatan yang berifat domestik saja, sementara laki-laki mendominasi urusan publik. Secara tradisional perempuan hanya berfungsi dan bertugas melahirkan dan membesarkan anak, menjaga anak, melanjutkan keturunan, mmasak dan mengurus rumah tangga. Kesejahteraan dan kemakmuran serta kebahagiaan suatu rumah tangga tergantung pada peranan perempuan sebagai ibu rumah tangga (Goode 2007). Perbedaan pandangan dan kedudukan perempuan dalam masyarakat berawal dari sosialisasi yang dilakukan oleh orang tua sejak dahulunya kepada anak-anak mereka, karena adanay anggapan dalam masyarakat bahwa kaum perempuan bersifat memelihara, rajin, dan tidak cocok menjadi kepala rumah tangga, maka akibatnya semua pekerjaan domestik menjadi tanggug jawab perempuan (Narwoko 2011).

Pada masyarakat primitif atau yang sudah tinggi tingkat perkembangan industrinya, lqki-lqki berkeberatan perempuan mengambil alih pekerjaan tingkat tinggi dan juga menolak untuk mengambil alih tugas-tugas perempuan. Pembagian pekerjaan ini dibenarkan oleh berbagai rasionalisasi dan perempuanperempuan moral semua itu merupakan bagian dari pada pengalaman sosialisasi anak laki-laki dan perempuan dalam masyarakat. Sejak dari mula anak laki-laki belajar untuk merendahkan beberapa macam pekerjaan sebagai pekerjaan perempuan dan memendang tinggi kepada pekerjaan yang lainnya sebagai kejantanan (Goode 2007).

Seiring dengan arus globalisasi, semakin disadari bahwa perempuan merupakan potensi penting dalam pembangunan. Hal ni terjadi krena kegagalan prose pembangunan dalam memahami dan mendukung peran reproduktif dan produktif perempuan di dalam rumah tangganya dan di dalam perekonomian informal, sehingga perempuan harus berjuang mempertahankan segalanya dalam proses pembangunan (Mosse 2007). Perempuan yang sadar mengenai keperempuanannya akan bergerak aktif dan untuk mendapatkan status yang sama dengan laki-laki dan juga mengadakan perbaikan kedudukan dalam masyarakat. Hal ini terjadi seiring dengan adanya gerakan emansipasi wanita, sehingga muncul pandangan masyarakat terhadap posisi perempuan yang mudah mengalami peningkatan. Salah satu kenyataan sumbangan prempuan dalam pembangunan adalah partisipasi perempuan dalam bidang ekonomi.

Jhon Naisbitt dan Patricia Aburdene mengindentifikasi bahwa era sekarang adaah era baru kebangkitan permpuan, tidak hanya di sektor usaha kecil, tapi juga pada posisi eksekutif, arsitek, pengacara, dan lain-lain (Danim 2004). Pada kenyataannya karena terbatasnya lapangan kerja, tenaga kerja perempuan kalah bersaing dengan tenaga kerja laki-laki, sehingga mereka hanya dapat memasuki pekerjaan-pekerjaan yang rendah (Abdullah 2006). Sektor informal adalah lahan yang selama ini banyak digarap oleh kaum perempuan sebagai tempat aktivitasnya. Sektor usaha informal adalah sektor usaha yang memiliki ciri-ciri yaitu, usahanya berskala kecil, kemampuan pengelolaan usaha biasanya diperoleh dari pengalaman dan tidak memerlukan pendidikan secara khusus, lebih cenderung bersifat padat karya, tempat usaha tidak tetap dan tidak terdaftar, tidak memiliki izin usaha yang resmi dari pemerintah. Contoh sektor usaha informal antara lain pengrajin, tukang ojek, pedagang kaki lima, tukang bakso, pedagang buah, dan sebagainya (Alma 2010).

Menurut Valentijin kegiatan-kegiatan seperti yang dikemukakan pada sektor ekonomi informal saat ini yang sudah ada sejak tahun 1724 di Kota Batavia (Jakarta). Dikatakannya bahwa saat itu di sepanjang jalan kota terdapat pedagang-pedagang yang berkeliling membawa segala macam barang yang diperdagangkan. Mereka menjual bermacam-macam sayuran, porselin, kain, barang kerajinan, teh, roti, telur, air minum, bunga, pakaian bekas, kaos kaki, dan lain lain (Alma 2010). Sampai pada saat sekarang, pedagang-pedagang makanan tidak hanya ada di Kota Batavia (Jakarta) tetapi di daerah-daerah Indonesia, seperti di daerah Sumtera Barat juga sudah ada pedagangpedagang makanan.

Salah satu contoh pedagang makanan yaitu pedagang asonagn. Keberadaan 
pedagang asongan dianggap penting di beberapa tempat. pedagang asonagn menjadi stimulan muncul dan berkembangnya usahausaha mikro dengan menjadi penyedia barang-barang dagangan yang dijajakan pedagang asongan. Peluang ini dimanfaatkan oleh kalangan indusrti menengah. Produsen minuman, koran atau rokok, misalnya, mulai banayak yang memanfaatkan pedagang asongan sebagai tenaga pemasar yang dapat secara langsung menyentuh konsumen (Ningsih 2012).

Para pedagang makanan asongan akan berusaha untuk menarik perhatian konsumen agar membeli barang dagangannya. Konsumen adalah aktor penting dalam ekonomi. Sifat dasar konsumen adalah memuaskan kepentingan (kebutuhan dan keinginan konsumsinya). Hal ini tentu akan berpengaruh penting pada aktivitas perekonomian. Bagi produsen, konsumen adalah sumber inspirasi dan sumber pendapatan untuk pengembangan usahanya. Oleh karena itu, produsen yang dapat memuaskan konsumen akan lebih mudah untuk mencapai tujuan usahanya (Noor 2007). Konsumen berbeda dengan pelanggan, konsumen adalah pemakai akhir sedangkan pelanggan sering kali diartikan sama dengan pembeli yang bertindak sebagai agen bagi konsumen akhir. Oleh karena itu, pedagang atau pemasaran sebaiknya tidah hanya mengerti apa yang diinginkan oleh pelanggan saja, tetapi juga keinginan atau kebutuhan konsuman akhir (Anogara 2004).

Sicincin merupakan nagari yang ada di Kabupaten Padang Pariaman, disini terdapat perempuan pedangang makanan asongan setiap hari dari pagi sampai sore, perempuan ini menjualkan dagangan dengan menggunakan baskom dan dijunjung diatas kepala, jenis makanan yang dijual mulai dari pisang rebus, telor asin, pinungkuik, tahu goreng dan kerupuk balado. Perempuan pedangang makanan asongan ini untuk menjualkan barang dagangannya cara naik turun bus dan ada juga yang hanya dari mobil ke mobil, seperti mobil pribadi. Bagi mereka yang menjual barang dagangan dengan naik turun bus, mereka berdagang membawa barang dagangannya penuh dengan risiko yang sangat berbahaya bagi dirinya sendiri, karena mereka naik dan turun bus sebelum bus tersebut berhenti.
Jumlah perempuan pedagang makanan asongan di sekitar Terminal Sicincin ini ada sebanyak 32 orang, yang terbagi atas dua tempat, yaitu di dekat Terminal Sicincin sebanyak 20 orang, 15 dari mereka berumur 28-50 tahun sedangkan 5 orang lainnya sudah berumur 50-65 tahun, dan di depan mesjid Jami' Muhammadiyah Sicincin sebanyak 12 orang, dan 8 orang berumur 30 50 tahun dan 4 orang berumur 50-65 tahun (wawancara awal dengan ibu murniati, 48 tahun). Dari sinilah penulis bagaimana aktifitas perempuan pedangang makanan di Terminal Sicincin? dan bagaimana kendala yang dialamin perempuan pedangang makanan dalam pekerjaannya?.

\section{TINJAUAN PUSTAKA}

Menurut Marleni dalam penelitiannya (Marleni 2007), yang berjudul "perempuan di Sektor Informal (Perempuan pembuat Kue di Cangkiang Nagari Batu Taba Kecamatan IV Angkatan Kabupaten Agam) yang membahas tentang konribusi ekonomi perempuan pembuat Kue Cangkaing dalam kehidupan keluarganya. Usaha tersebut telah menjadikan mereka sebagai penggerak perekonomian kelurga dan masyarakat Cangkiang (secara umum). Selain itu, keberadaan mereka sebagai penggerak perekonomian berpengaruh pila pda relasi gender dalam keluarga mereka (secara khusus). Peran laki-laki sebagai pencari nafkah utama dalam kelurga sudah tergantikanoleh perempuan. Kondidi tersebut berpengaruh terhadap sikap dan tindakan masing-masing anggota keluarga serta hubungan gender dalam kelurga.

Jelita menuturkan yang dalam penelitiannya berjudul "fenomena Istri Berperan Ganda Terhadap Rumah Tangga Di Kenagarian Pakan Raba'a Kecamatan Koto Parik Gadang Diateh Kabupaten Solok Selatan" yang menyimpulkan bahwa di kenagarian Pakan Raba'a banyak terdapat istri yang berperan ganda yaitu sebagai pegawai Negeri Sipil (PNS), karyawan swasta, pedagang dan petani. Terkadang keadaan tersebut menimbulkan kecemasan bagi ibu yang menjalani peran ganda tersebut. Lingkungan dan dirinya sendiri menginginkan untuk menjadi seorang ibu, sekaligus istri yang baik yang dapat memenuhi semua kebutuhan termasuk kebutuhan spiritual dan emosional anak. 
Disaat yang sama ia juga ingin agar pekerjaannya berjalan baik-baik saja. Kedua peran yang dilakukan oleh ibu yang tersebut tentunya mempunayi konsekuensi tersendiri apabila keduanya tidak terlaksana dengan baik (Jelita 2009). Dalam penelitian (Amarta 2012), "Tindakan Pedagang Asongan Di RSUP DR. M. Djamil Padang" menyimpulkan bahwa tindakan yang dilakukan oleh pedagang asongan dalam berjualan di RSUP Dr. Djamil Padang merupakan uatu tindakan yang rasional, dimana dalam mengambil tindakan telah ada pertimbanagn dan pilihan sadar yang berhubungan dengan tujuan tindakan itu. Tindakan yang dilakukan oleh pedagang asongan dalam berjualan di RSUP Dr. M Djamil Padang antara lain; (1) berjualan sebelum satpam datang, (2) berjualan dengan cara cilok-cilok, (3) berjualan dengan menyembunyikan dagangan dan duduk di sekitar keluarga dari pasien yang rawat inap, (4) berjualan pada jam besuk, (5) berjualan dengan mengikuti aturan yang sudah ditetapkan, (6) menjalin hubungan baik dengan satpam atau pihak rumah sakit. Dengan tindaka yang dilakukan oleh pedagang asongan tersebut, pedagang asongan Bisa tetap berjualan di dalam kompleks rumah sakit untuk mengejar pembeli.

\section{METODE PENELITIAN}

Metode yang digunakan melalui pendekatan kualitatif dengan tipe deskriptif. Lokasi penelitian di Terminal Sicincin Kabupaten Padang Pariaman, dengan menggunakan metode pengumpulan data yaitu observasi, wawancara mendalam dan studi dokumen. Analisis data menggunakan Milles dan Huberman yaitu pengumpulan data, reduksi data, display data dan penyajian data

\section{LATAR BELAKANG PEREMPUAN PEDAGANG MAKANAN ASONGAN}

Perempuan merupakan sumber daya yang memiliki kemampuan, kemampuan yang dimiliki perempuan tidak hanya sebagai ibu rumah tangga, tetapi juga mampu berperan dalam pekerjaan yang menghasilkan uang, dalam artian potensi mencari nafkah. Peran tersebut seperti yang dijalankan perempuan pedagang makananasongan di sekitar Terminal
Sicincin yang menghasilkan uang untuk memenuhi kebutuhan keluarga.

sejalan dengan pembangunan yang terjadi dalam masyarakat, dari masyarakat tradisional menuju masyarakat modern dan diiringi pertambahan penduduk serta tuntutan ekonomi yang sedemikian kompleks mengakibatkan perubahan peran dalan masyarakat. Perempuan tidak hanya menggeluti sektor domestik saja tetapi telah memasuki sektor publik. Hal ini mengakibatkan pergeseran dari ibu rumah tangga menjadi perempuan yang ikut berperan dalam membantu ekonomi keluarga.

Khususnya di Sicincin kebanyakan perempuan tidak hanya berperan sebagai ibu rumah tangga tetapi memiliki peran dalam mencari nafkah, karena kebanyakan dari perempuan Sicincin bekerja sebagai pedagang makanan asongan, jadi pekerjaan sebagai pedagang makanan asongan merupakan pekerjaan bagi perempuan Sicincin yang tidak memiliki keahlian lainnya. Adanya Terminal Sicincin dan Mejid Jmi' Muhammadiyah Sicincin, mereka dapat memanfaatkan tempat tersebut untuk mencari nafkah. Ada beberapa yang melatarbelakangi perempuan untuk berdagang makanan, yaitu:

\section{Warisan Pekerjaan,}

Setiap orang selalu berusaha untuk mampu mendapatkan pekerjaan yang layak sehingga mereka berlomba-lomba untuk mencari pekerjaan demi memenuhi kebutuhan hidup sehari-hari, seperti menjadi dokter guru, pengusaha dan lain sebagainya. Sekian banyaknya pekerjaan yang digeluti oleh masyarakat, pekerjaan di sektor informal juga masih banyak dgeluti oleh perempuan, salah satunya pekerjaan sebagai pedagang makanan asongan. Salah satu alasan yang melatar belakangi perempuan bekerja sebagai penajaja makanan asongan karena merupakan pekerjaan turun temurun dari orang tua, seperti yang diungkap oleh ibu Hazumarni (40 tahun):

$$
\begin{aligned}
& \text { "ibu bekerja menjajakan } \\
& \text { makanan ini sudah lama, } \\
& \text { semenjak ibu gadis kira-kira } \\
& \text { sudah } 15 \text { tahun lebih. Menjajakan } \\
& \text { makanan dengan mengasong }
\end{aligned}
$$


seperti ini sudah turun temurun dari orang tua perempuan ibu sampai saat sekarang ibu yang melanjutkannya" (Wawancara, tanggal 31 agustus 2013).

Hal yang senada juga dilakukan diungkapkan oleh ibu Eliza (37 tahun):

"menjajakan makanan sudah menjadi tradisi dari keluarga ibu. Semenjak dari orang tua perempuan ibu sampai kekami anak-anaknya tetap menjajakan makanan. Pada masa itu orang tua perempuan ibu hanya penjual makanan asongan, tidak ada pekerjaan lain, sehingga menjajakan makanan dengan mengasong sudah menjadi pekerjaan yang biasa kami lakukan" (Wawancara, 04 September 2013).

\section{Memenuhi Kebutuhan Keluarga}

Kebutuhan merupakan pokok utama bagi manusia untuk menjalani hidupnya. Manusia memerlukan kebutuhan untuk memenuhi kebutuhan hidupnya. Kebutuhan manusia sangat banyak, salah satunya adalah kebutuhan primer, sekunder dan tersier. Tapi, kebutuhan yang paling utam yang harus dipenuhi manusia adalah kebutuhan primer yaitu kebutuhan sandang, pangan, dan papan. Selain karena sudah pekerjaan yang turun menurun dari orang tua, hal paling dominan yang melatar belakangi perempuan bekerja sebagai pedagang makanan asongan adalah untuk memenuhi kebutuhan keluarga. seperti yang diungkapkan oleh ibu Fitmawati (50 tahun):

"ibu menjajakan makanan untu memenuhi kebutuhan keluarga karena ibu sudah tidak ada suami lagi, suami ibu sudah lama meninggal, kira-kira sudah 15 tahun. Sehingga kebutuhan keluarga ibu yang menanggungnya, apalagi anakanak ibu masih ada yang sekolah. Walaupun ada 1 orang anak ibu sudah bekerja, tapi untuk keperluan sehari-hari dan biaya sekolah adik-adiknya tidak mungkin ibu beratkan padanya seorang diri. Makanya ibu juga berusaha untuk mencari uang" (Wawancara, tanggal 08 September 2013).

\section{Pendidikan}

Pendidikan juga merupakan salah satu yang sudah menjadi kebutuhan bagi manusia. Pendidikan sangat penting ukearah yang lebih baik dimasa depan. pendidikan menjadikan manusia lebih terpandang, berwibawa, dan mengangkat derajat seseorang. Hasil penelitian menunjukkan, bahwa ditinjau dari segi pendidikan perempuan pedagang makanan asongan relatif rendah.

Alasan perempuan memilih bekerja sebagai penjaja makanan asongan karena pendidikan yang rendah dan keterampilan yang kurang. Ditinjau dari hasil penelitian, dari segi pendidikan perempuan penjaja makanan asongan memiliki pendidikan yang relatif rendah. Hal ini senada dengan yang diungkapkan oleh ibu Mariyenti (38 tahun):

"Mau bagaimana lagi, ibu sekolah cuma sampai SD, ibu hanya bisa sekedar membaca dan menulis saja, orang tua ibu tidak sanggup untuk membiayai ibu untuk sekolah. Jangankan untuk sekolah, untuk makan saja susah. Sehingga untuk membantu suami mencukupi kebutuhan keluarga, ibu hanya bisa menjajakan makanan, karena ibu tidak memiliki kehlian lain" (Wawancara, tanggal 07 September 2013).

Senada dengan ibu Mariyenti, alasan Ibu Murniati (48 tahun) juga hampir sama seperti yang diungkapkannya berikut ini:

"Ibu sekolah hanya sampai tamat SD dan pengalaman ibu juga tidak banyak untuk pekerjaan yang lain. Selain menjajakan makanan ini ibu hanya bisa kesawah, tetapi kalau untu kesawah itu ada suami bu, jadi ibu lebih memilih menjajakan makanan dengan 
mengasong seperti ini. Karena ibu tidak ada pengalaman dan tidak bisa bekerja yang lain, makanya ibu hanya berjualan makanan seperti ini" (Wawancara, tanggal 07 September 2013).

Berbeda dengan yang lainnya, Ibu Nisa Yang sudah berumur 65 tahun, memiliki alasan masih tetap memanjakan makanan asongan karena keinginan sendiri, seperti yang diungkapkannya dalam hasil wawancara berikut:

"Walaupun ibu sudah tua-tua begini, tapi ibu lebih suka untuk mencari uang sendiri. Ibu tidak mau terlalu bergantung pada anak-anak, apalagi mereka sudah berkeluarga. Menjajakan makaanan seperti inilah yang bisa ibu lakukan setiap harinya, tapi ibu tidak naik dan turun bis, karena menginagat keadaan dan kondisi badan ibu. Dulunya ibu sekolah tidak sampai tamat SD, karena kondisi orang tua yang susah" (Wawancara, tanggal 27 Agustus 2013).

\section{Keterbatasan Model (Uang)}

Suatu usaha yang dilakukan manusia seperti membuka lapangan pekerjaan merupakan salah satu usaha tersebut, hal yang paling utama yag harus disediakan adalah modal. Modal secara umum diartikan sebagai uang, artinya bahwa kunci untuk memulai suatu usaha yang dibutuhkan adalah uang yang kita miliki. Sedangkan salah satu faktor perempuan bekerja sebagai penjaja makanan asongan karena tidak membutuhkan modal sama sekali. Mereka bekerja sebagai penjaja makanan dengan orang orang yang membuat makanan (induk Semang).

Seperti yang diungkapkan oleh ibu fitriyani (41 tahun), memilih bekerja sebagai penjaja makanan asonagn karena karena sebelumnya ditimpa musibah di rantau, dan akhirnay pulang kekampung halaman sehingga untuk membuka usaha lain ini tidak memiliki modal lagi, sepertiyang diungkapkannya dalam wacana berikut:

\begin{abstract}
"sebelum ibu berdagang makanan ini, ibu pernah merantau ke Brunai Darussalam selama 11 tahun lamanya. Di sana ibu sudah membuka bebrapa toko. Tapi karena suatu kecelakaan, toko-toko ibu habis terbakar dan ibu banyak mengalami kerugian. Sehingga ibu pulang kekampung dan memilih untuk bekerja menjajakan makanan asongan seperti ini, dari pada hanya berdiam diri di rumah" (Wawancara, tanggal 04 September 2013).
\end{abstract}

\section{AKTIVITAS PEREMPUAN PEDAGANG MAKANAN ASONGAN}

Atifitas perempuan pedagang ini dilihat dari alokasi waktu, interaksi antar sesama pedagang makanan asongan, dan kiat penguasaan situasi pasar bagi pedagang makanan,

\section{Alokasi Waktu}

Dewasa ini konsep jati diri
perempuan
keikutsertaan berupa partisipasi dalam pembangunan. Perkembangan semacam ini bukanlah perkembangan revolusioner, akan tetapi perkembangan ini telah berproses dalam waktu yang cukup lama. Laju pertumbuhan modernisasi yang demikian pesat menuntut perempuan untuk ikut dalam pekerjaan publik seperti berdagang makanan asongan. Sementara ada beberapa pendapat yang memandang sinis terhadap kegiatan perempuan, karena sejak lama sudah ada pandangan dalam masyarakat bahwa perempuan hanya mempunyai tugas dan kewajiban mengurus kepentingan di dalam ingkungan rumah tangga dan tidak perlu bekerja di luar ugas tersebut.

Nilai-nilai yang terkandung dalam masyarakat juga sering mengaitkan bahwa perempuan hanya berurusan dengan pekerjaan dalam rumah (domestik). Perempuan diistilahkan ebagai housewife (ibu rumah tangga) yang bertanggung jawab dengan pekerjaan rumahnya, merawat anak, dan 
mendidik anak. Sedangkan laki-laki lebih banyak dikaitkan dengan pekerjaan di luar rumah (publik). Namun demikian didorong oleh rasa tanggung jawab atas kelangsungan kesejahteraan keluarga, maka perempuan di Sicincin ikut mencari nafkah. Salah satunya dengan bekerja sebagai pedagang makanan asongan. Pekerjaan ini memiliki pengaruh terhadap fungsi-fungsi yang mereka jalankan. Sebagai ibu rumah tangga perempuan tersebut harus dijalankan oleh perempuan adalah mengasuh dan mendidik anak, mengatur rumah tangga, dan menjalankan fungsinya di dapur.

Dari pernyataan di atas terlihat bahwa peranan domestik perempuan sebagai pengatur rumah tangga sudah terabaikan. Tugas sesorang ibu dan istri beralih kepada anak dan suami. Peralihan ini terjadi setelah perempuan bekerja sebagai penjaja makanan asongan. Akibat lain dari dampak perempuan bekerja terhadap peranan domestiknya adalah hubungan ibu dan anak juga mengalami pergeseran. Sejak lahir anak lebih dekat dan erat hubungannya dengan ibu. Hasil wawancara dengan ibu fitriyani (41 tahun 2013):

"Ibu di sini tinggalnya menmpang sama saudara ibu, suami ibu pekerjaannya sopir dan jarang pulang. Selama ibu pergi berjualan, anak-anak ibu untuk berkumpul dengan anak-anak tidur. Kalau pekerjaan rumah seperti memasak dan mencuci ibu kerjakan pada subuh hari sebalum berangkat berjualan. Sekitar jam 08.00 pagi ibu sudah berangkat untuk berjualan dan jam 07.00 malam baru pulang kerumah" (Wawancara, tanggal 04 September 2013).

Hampir senada dengan yang diungkapkan oleh ibu hazumarni (40 tahun) sebagai berikut:

"setelah sholat subuh, ibu selalu mengerjakan pekerjaan rumah seperti memasak dan mencuci kalau bersih-bersih rumah anak ibu yang perempuan yang mengerjakannya. Setiap harinya ibu brjualan dari jam 0.8.00 pagi sampai jam 0.5.00 sore. Sebelum pulang kerumah ibu mampir dulu ketempat induk semang untuk membayar brang dagangan yang diambil hari ini sekaligus memesan barang dagangan untuk besok harinya" (wawancara, tanggal 31 Agustus 2013).

Seperti yang diungkapkan oleh ibu Murniati (48 tahun) sebagai berikut: "setelah selesai semua pekerjaan rumah, ibu baru berangkat berjualan. Ibu berangkat jam 08.00 pagi dan pulang jam 06.00 sore. Kalau memasak ibu lebihkan yang pagi sampai untuk malamnya, jadi ibu cukup memasak 1 kali dalam sehari saja" (Wawancara, tanggal 27 Agustus 2013).

Hal ini senada juga diungkapkan oleh ibu Eliza (37 tahun) sebagai berikut:

"Selain menjajankan makanan ini ibu tidak memiliki pekerjaan lain, ibu berjualan mulai dari jam 09.00 pagi sampai jam 05.00 sore. Pekerjaan rumah ibu dikerjakan sebalum berangkat berjualan. Terkadang karena mengurus rumah tangga dan mengurus anak sebelum berangkat sekolah, ibu sering terlambat untuk berjualan" (Wawancara, tanggal 04 September 2013).

Berbeda dengan ibu Nurhayati, yang hanya tinggal sendiri karena anakanaknya yang sudah berkeluarga dan tinggal dirumah masing-masing. Pekerjaan rumah tidaklah terlau menjadi beban baginya, karena bisa dikerjakan kapanpun dia bisa. Seperti yang dikatakan ibu Nurhayati (53 tahun) sebagai berikut:

"karena sekarang ibu tinggal sendiri, anak-anak sudah berkeluarga, jadi masalah pekerjaan rumah tergantung kapan maunya ibu mengerjakannya saja. Terkadang 
kalau sempat sebelum berangkat berjualan ibu kerjakan, tapi kalau tidak, ibu kerjakan setelah pulang" (Wawancara, tanggal 31 Agustus).

Hal ini juga diungkapkan oleh ibu Nisa (65 tahun):

"dari ibu mulai berjualan kirakira 15 tahun sampai sekarang, yang namanya pekerjaan rumah semuanya ibu serahkan pada anak-anak. Ibu pergi berjualan mulai jam 10.00 pagi sampai jam 06.00 sore. Ibu hanya pergi berjualan saja apalagi semenjak suami ibu meninggal, yang mencari uang hanya ibu sendiri, anak-anak ibu berlima yang ibu biayai. Tapi, sekarang anak ibu sudah ada yang menikah, jadi beban ibu sudah berkurang juga" (Wawancara, tanggal 27
Agustus).

Berdasarkan hasil wawancara dengan informan menyebutkan bahwa dengan bekerja sebagai penjaja makanan asogan yang menghabiskan waktu dari pagi sampai sore, mereka harus pagipagi sekali bangun untuk menyelesaikan pekerjaan rumah dan baru berangkat untuk berjualan. Seperti yang diungkapkan oleh ibu fitmawati (50 tahun):

"Untuk pergi berjualan menjajakan makanan setiap harinya ibu berangkat dari rumah jam 06.00 pagi dan ibu langsung pergi ketepat induk semang untuk mengambil barang dagangannya. Karena pekerjaan dirumah seperti memasak ibu yang mengerjakannya, tapi memasak nasi dan bersi-bersih rumah dibantu oleh suami ibu, maka ibu bisa cepat dari temanteman yang lain, sehingga barang dagangan yang ibu ambil lumayan. Ibu pulang kerumah jam 06.00 sore. Tapi sebelum pulang ibu mampir dulu ke induk semang untuk mengembalikan kalau ada barang dagangan yang tidak habis terjual sekaligus membayar barang dagangan yang diambil hari ini" (Wawancara, tanggal 08 September 2013).

Hal ini hampir senada yang diungkapkan oleh Ibu Farida (49 tahun):

"Ibu berangkat berjualan dari rumah jam 10.00 pagi dan pulang jam 06.00 sore. Antara pekerjan rumah dengan berjualan tidak ada yang jadi masalah bagi ibu, karena pekerjaan rumah ibu serahkan pada anak-anak, makanya ibu hanya pergi berjualan saja. Anak-anak ibu pun mengerti, mungkin karena ibu sekarang menjadi tulang punggung keluarga, yang mencari uang Cuma ibu, suami ibu sudah lama meninggal" (Wawancara, tanggal 08 September 2013).

Ungkapan dari beberapa informan di atas jiga didukung dengan wawancara peneliti dengan anggota keluarga informan, seperti ungkapan Bapak Irzal (57 tahun), suami ibu Fitmawati sebagai berikut:

"Sebenarnya Bapak tidak tega membiarkan ibu mencari uang sndiri, tapi karena kondisi badan Bapak ang sering sakit-sakitan dan tidak sanggup lagi bekerja, makanya pekerjaan rumah selain memasak, Bapak yang membantu, seperti membersihkan rumah dan memasak nasi" (Wawancara, tanggal 06 Oktober 2013).

Pekerjaan yang dilakukan perempuan untuk berdagang makanan ini tidak menggunakan modal (uang) dikarenakan modal atau makanan yang dijual oleh perempuan diambil dari orang-orang yang membuat makanan (iduk semang), perempuan hanya menjual dagangan tanpa arus mengeluarkan modal dan waktu dalam membuak makanan tersebut. Perempuan pedagang makanan mejualkan makanannya mulai dari pagi hingga sore harinya, sebelum berdagang perempuanperempuan ini menjalankan tugas dan perannya dalam keluarga seperti 
sebelum mereka berangkat berjualan perempuan ini mempersiapkan pekerjaan rumah seperti mempersiapkan makanan, mempersiapkan kebutuhan anak buat kesekolah. Berikut alokasi waktu perempuan yang berdagang makanan asongan, dapat dilihat pada tabel 1 dibawah ini.

Tabel 1

Deskripsi Alokasi Waktu

\begin{tabular}{|l|l|c|c|c|c|}
\hline \multirow{2}{*}{ No } & \multicolumn{1}{|c|}{$\begin{array}{c}\text { Nama } \\
\text { Informan }\end{array}$} & \multicolumn{4}{|c|}{ Alokasi Waktu Bekerja Dalam Sehari (WIB) } \\
\cline { 3 - 6 } & $\begin{array}{c}\text { Bangun } \\
\text { Tidur }\end{array}$ & $\begin{array}{c}\text { Pekerjaan rumah } \\
\text { tangga }\end{array}$ & $\begin{array}{c}\text { Brangkat } \\
\text { Berjualan }\end{array}$ & $\begin{array}{c}\text { Pulang } \\
\text { Berjualan }\end{array}$ \\
\hline 1 & FY itriyani & 04.30 & $05.00-07.00$ & 08.00 & 19.00 \\
\hline 2 & Eliza & 04.30 & $05.00-08.00$ & 09.00 & 17.00 \\
\hline 3 & Mariyenti & 05.00 & $18.00-20.00$ & 08.00 & 17.00 \\
\hline 4 & Nurhayati & 05.00 & $05.30-07.30$ & 08.00 & 17.00 \\
\hline 5 & Murniati & 04.30 & $05.00-07.00$ & 08.00 & 18.00 \\
\hline 6 & Hazumarni & 05.00 & $05.15-07.00$ & 08.00 & 17.00 \\
\hline 7 & Farida & 05.00 & $05.30-06.00$ & 10.00 & 18.00 \\
\hline 8 & Fitmawati & 04.30 & $05.00-06.00$ & 06.00 & 18.00 \\
\hline
\end{tabular}

Sumber: Data Primer 2013

\section{Interaksi Sesama Pedagang}

Manusia adalah makhluk sosial, yang saling membutuhkan satu sama lain. Mereka harus melakukan interaksi baik secara individu maupun kelompok. Kebutuhan akan ubungan atau interaksi dengan orang lain erat kaitannya dengan pernyataan bahwa manusia merupakan makhluk sosial yang hidup bersama. Hidup bersama atau bermasyarakat artinya asama dengan hidup dalam suatu pergaulan, oleh sebab itu manusia sebagai makhluk yang saling membutuhkan satu sama lainvharus menjalin interaksi dengan baik.

Di dalam menjalin interaksi antara sesama perempuan penajaja makanan asongan, hampir tidak ditemui orang yang tidak saling mengenal satu sama lain. Meskipun dalam menjalankan aktivitas sebagai pedagang makanan asongan yang harus berebut satu sama lain untuk mendapatkan pembeli, tapi hal tersebut tidak menghalangi interaksi dan hubungan sosila diantara mereka. Interaksi yang terjadi antar sesama pedagang makanan asongan ada beberapa yaitu:

\section{a. Kerjasama}

Hubungan sosial dalam interaksi yang terjalin anatar sesama perempuan pedagang makanan songan relatif baik, karena adanya rasa kebersamaan dan rasa senasib sepernanggungan. Hal tersebut menimbulkan kerjasama di anatara mereka, sehingga mereka saling membantu satu sama lain dalam berbagai hal. Tampak jelas hubungan sosial dan interaksi antara pedagang makanan cukup baik. Selain melakukan wawancara terhadap informan, peneliti juga mengamati secara langsung, bahwa dalam proses berjualan, mereka saling bantu membantu jika makanan yang mereka jual tidak tersedia, maka mereka memanggil perempuan pedagang makanan yang lain menyediakan makanan sesuia permintaan pembeli.

Seperti yag diungkapkan oleh ibu Murniati sebagai berikut:

"Walaupun ibu berebut mengejar pembeli dengan ibu-ibu yang lain, tapi rasa kebersamaan di sini cukup erat. Dan rasa persaingan yang ada dalam berdagang rasanya sudah tidak terasa lagi, karena kami di sini bisa saling bergaul dengan baik" (Wawancara, tanggal 27 Agustus 2013). 
Hal senada juga disampaikan oleh ibu Farida sebagai berikut:

"Kami di sini sudah seperti keluarga. Dalam menjajakan makanan ini kami tetap menjalin kerjasama anatar sesama, sepertp pada saat menjual makanan ke mobil-mobil yang berhenti di sini, kalau ada pembeli yang mau membeli makanan, tapi makanan tersebut tidak tersedia sama ibu, maka ibu panggilkan teman ibu yang ada menjual makanan tersebut" (Wawancara, tanggal 08 September 2013).

Hal ini membuktikan adanya kepedulian mereka terhadap sesama pedagang makanan asongan. Bentuk kerjasama yang lain dari perempuan pedagang makanan asongan yaitu saling menolong dari segi meminjamkan uang bagi perempuan yang memerlukan uang untuk kebutuhan yang mendesak, selain itu juga bentuk kerjasama yang lain dari pedagang makanan ini terlihat waktu mereka berkenjung kerumah salah satu pedagang yang sakit. Dari sini bentuk kerjasama sesama pedangang terjalin yang sangat kuat antara sesama pedagang. Seperti yang diungkapkan oleh ibu Fitmawati:

"Kami di sini hidup saling bantu membantu, kalau ada yang sedang butuh pinjaman, pasti ada diantara kami ini yang mau meminjamkan. Walaupun pinjaman itu tidak seberapa, tapi alhamdulilah bisa untuk menutupi kekurangan yang dibutuhkan" (Wawancara, tanggal 08 September 2013).

Adanya rasa peduli akan sesama diantara perempuan penjaja makanan asongan menimbulkan rasa kekeluargaan yang tinggi diantara mereka, hal yang sama senada juga disampaikan oleh Ibu Nisa sebagai berikut:

"Selama ibu menjajakan makanan sepeti ini dari dulu sampai sekarang semuanya tetap sama. Bagi ibu, penajaja makanan yang masih muda-muda ini sudah seperti anak-anak ibu sendiri. Mereka di sinisering memperlakukan ibu dengan baik, apalagi melihat keadaan ibu yang sudah tua dam masih juga berdagang" (Wawancara, tanggal 27 Agustus 2013).

\section{b. Persaingan}

Persaingan merupakan hal yang sudah biasa bagi para pedagang, terutama bagi perempuan pedagang makanan asongan, karena mereka harus berebut satu sama lain dalam mengejar pembeli, Seperti yang diungkapkan oleh ibu fitriyani sebagai berkut:

"Dalam menjajakan makanan ini tentu ada persaingan, apalagi dalam mengejar pembeli. Tapi kami di sini tidak terlalu menampakkan persaingan itu, karena kalau menurut ibu rezeki sidah ada untuk kita masingmasing. Jadi tidak harus terlalu dipermasalahkan" (Wawancara, tanggal 04 September 2013).

Walaupun persaingan diantara perempuan pedagang makanan asongan tidak terlalu dipermasalahkan, tapi dalam hal mengejar pembeli sangat jelas kalau persaingan itu memang ada. Apalagi pada saat ada mobil pembeli yang berhenti untuk membeli barang dagangan mereka, maka mereka akan saling berebut menuju mobil tersebut. Hal yang sama juga diungkapkan ole ibu Eliza sebagai berikut: "Kalau ada mobil yang sengaja berhenti di sini , walaupun mobil tersebut berhenti belum tentu untuk membeli barang dagangan ibu, tapi ibu tetap menawarkan makanan ang ibu jual kepenumpang mobil tersebut. Malahan bukan hanya ibu saja yang seperti itu, tapi temanteman yang lain juga ikut menawarkan pada penumpang mobil yang sama, sehingga kami sama-sama berusaha menawarkan dagangan Masingmasing"(Wawancara, $\quad 04$ September 2013). 
Persaingan dalam berdagang makanan hanya sekedar untuk mencari keuntungan dari berdagang, saling berebutan ini sudah menjadi kebiasaan bagi pedagang makanan, saling menawarkan makanan kepada pembeli memperlihatkan persaingan ini hanya untuk mencari keuntungan saja, dikarenakan makanan yang di dagangkan oleh perempuan juga diambil dari orang-orang yang membuat makanan tersebut (iduk semang).

\section{KIAT PENGUASAAN SITUASI PASAR}

Terminal Sicincin merupakan salah satu tempat kegiatan perempuan pedagang makanan asongan dalam melakukan aktivitas ekonomi, dengan tujuan untuk memenuhi kebutuhan hudup sehari-hari. Kiat hampir sama dengan strategi, dalm artian merupakan rencana atau rancanagan yang cermat mengenai kegiatan yang akan dilakukan untuk mencapai sasaran khusus agar tujuan yang ingin dicapai berjalan sesuai dengan apa yang diinginkan dan kegiatan yang dijalankan berjalan dengan lancar.

Kiat atau strategi yang baik akan menghasilkan keserasian dan keselarasan antara individu dan lingkungan, dalam rangka untuk memenuhi kebutuhan hidup dan keseimbangan antara yang satu dengan yang lain, kiat dari penguasaan situasi pasar seperti 1) memamfaatkan hari libur, Faktor utama yang menentukan banyak sedikitnya pendapatan yang diperoleh oleh perempuan pedagang makanan asongan adalah kondisi pembeli. Artinya, apabila pembelinya ramai pendapatan yang diperoleh penjual makanan tinggi, tapi apabila pembelinya sepi maka pendapatan yang diperolehpun sedikit. 2) pembeli ingin didatangi, Kesempatan yang digunakan oleh perempuan pedagang makanan asongan dalam mengejar pembeli tidak hanya dilakukan di sekitar Terminal Sicincin saja. Perempuan pedagang makanan asongan tidak hanya menunggu mobil atau bus yang berhenti dan menjual barang dagangan dari luar saja, tapi mereka lebih aktif untuk naik keatas Bus agar barang dagangannya bisa terjual habis. 3) memberikan potongan harga bagi pembeli, Keuntungan yang diperoleh dari berdagang menjualkanmakanan asongan tidak seberapa, karena makanan-makanan yang dijajakan tersebut harganya juga tiak tinggi.
Walaupun demikian dalam menarik pembeli, perempuan pedagang makanan asongan tetap memberikan potongan harga bagi pembeli agar barang dagangannya tetap laku dan pembeli juga merasa senang berbelanja. 4) sudah terbentuknya image telur asin dan pisang jantan rebus, Derah Sicincin merupakan daerah yang khas bagi masyarakat umum, karena di daerah Sicincin terdapat keunikan makanan dibandingkan di daerah-daerah lainnya khususnya di Sumatera Barat. Dimana daerah Sicincin merupakan daerah yang selalu menyediakan barang dagangan berupa telur asin dan pisang jantan rebus yang di jual oleh perempuan pedagang makanan asongan setiap harinya. Telur asin dan pisang jantan rebus adalah ciri khas tersendiri bagi daerah Sicincin. Sehingga telur asin dan pisang jantan rebus dijadikan sebagai buah tangan bagi orang-orang yang melewati daerah Sicincin. Dalam menjualkanmakanan yang terpenting bagi penjual adalah selalu menyediakan telur asin dan pisang jantan rebus karena makanan utama yang dicarai pembeli di daerah Sicincin adalah telur asin dan pisang jantan rebus

\section{KENDALA-KENDALA PEREMPUAN PEDAGANG MAKANAN}

Menjualkan makanan dengan cara mengasong merupakan salah satu tindakan ekonomi yang dilakukan perempuan untuk memenuhi kebutuhan keluarga. Artinya keterlibatan perempuan bukan saja melibatkan kegiatan reproduksi, tetapi jug kegiatan produktif untuk menghasilkan pendapatan. Pilihan usaha perempuan untuk terlibat kegiatan produktif terbatas, disebabkan keterbatasan sumber daya dan akses yang dimiliki. Salah satu usaha yang dapat dilakukan oleh perempuan yaitu berdagang, contohnya perempuan pedagang makanan asongan yang banyak ditemui di sekitar Terminal Sicincin.

Dalam menjalankan aktivitas, perempuan pedagang makanan asongan. Hal ini terjadi karena aktivitas yang dijalani perempuan pedagang makanan asongan menghaBuskan waktunya sehari-hari untuk berjualan makanan dan juga mengalami kendala dalam berdagang makanan seperti. 1) sopir dan penumpang bus tidak bersahabat, pada saat perempuan menjualka nmakanan ke atas bus hal yang sering 
mereka alami adalah sikap sopir dan penumpang Bus yang tidak bersahabat. Adakalanya mereka mendapat sambutan yang baik dari penumpang ataupun sopir Bus, dan ada juga yang marah karena merasa terganggu. Agar tetap bisa bertahan hidup dan memenuhi kebutuhan keluarga, perempuan pedagang makanan harus tetap tegar dalam penjalani perannya. 2) tidak adanya SPBU, Selain itu, hal yang menghalangi perempuan melakukan aktivitas menjualkanmakanan asongan yaitu, ketiadaan SPBU. SPBU Sicincin atau bersebelahan dengan Mesjid Jami' Muhammadiyah Sicincin, yang merupakan salah satu tempat yang sering dimanfaatkan unruk berdagang oleh perempuan pedagang makanan asongan, karena bi maupun mobil banayak yang berhenti di sana untuk pengisian BBM. Tapi setelah hari raya idul fitri 1434 Hijriyah, SPBU tersebut dieksekusi karena pemilik tanahnya berkonflik. 3) pembeli pada hari-hari tertentu, pembeli merupakan salah satu faktor yang menentukan pendapatan yang diperoleh perempuan pedagang makanan asongan, banyak sedikitnya, barang dagangan yang haBus terjual tergantung pada konumen atau pembeli. Keadaan pembeipun juga menjadi kendala bagi penajaja makanan asongan dalam menjual barang dagangannya. Volume kendaraan yang lewat di jalur Terminal Sicincin setiap harinya juga berbeda-beda, sehingga hal ini juga menjadi kendala bagi pata pedagang makanan asongan. Berdasarkan volume kendaraan yang lewat tersebut menjadi patokan berapa banyak pembeli

\section{ANALISIS KEUNTUNGAN PADA PROSPEK USAHA DAN DUKUNGAN KELUARGA}

Berdagang merupakan pekerjaan yang dilakukan seseorang dengan harapan memperoleh keuntungan dari setiap barang dagang yang dijual. Begitu juga halnya dengan perempuan pedagang makanan asongan. Walaupun dalam menjalankan aktivitas berdagang mereka tidak membutuhkan modal, tapi mereka tetap mengharapkan keuntungan dari setiap barang dagangan yang mereka jual. Untuk mendapatkan keuntungan tersebut, perempuan pedagang makanan asongan harus bisa memainkan harga. Dari setiap komoditi yang mereka jual harganya berbeda-beda. Mereka menetapkan harga jual kepada pembeli tergantung pada harga yang ditetapkan oleh pembuat makanan.

Dukungan merupakan sebuah motivasi yang diharapkan sesorang dari orang lain. Dukungan dapat memberikan semangat baik dalam bekerja maupun dalam meraih sesuatu. Begitu juga dengan perempuan pemnjaja makanan asongan yang juga dukungan-dukungan dari keluarganya untuk dapat berjualan setiap hari. Ada juga perempuan pedagang makanan asongan ini memiliki harapan yang besar terhadap anakanak yang mereka sekolahkan kejenjang yang lebih tinggi. Model dukungan yang diharapkan oleh permpuan pedagang makanan asongan yaitu berupa dukungan moril, seperti motivasi dan semangat untuk berjualan. Walaupun pekerjaan sebagai pedagang makanan asongan menghabiskan waktu seharian, tapi bagi perempuan pedagang makanan asongan, pekerjaan rumah juga penting. Untuk itu mereka juga menaruh harapan yang besar agar keluarganya bisa memahami pekerjaan yang harus dikerjakannya

Berdasarkan teori yang dipakai oleh peneliti yaitu Teori Exchange (PertukaranPerilaku) dari Homans, yang mengemukakan 5 proposisi yaitu proposisi sukses, proposisi stimulus, proposisi nilai, proposisi deprivasisatiasi, dan proposisi restu-agresi. Setelah melakukan penelitian dan berdasarkan hasil pembahasan, maka peneliti mengaitkan permasalahan yang di kaji lebih ditekankan pada proposisi nilai. Proposisi nilai merupakan memberikan nilai kepada tingkah laku yang diserahkan oleh orang lain terhadap aktor. Makin bernilai bagi seseorang tingkah laku orang lain yang ditujukan kepadanya makin besar kemungkinan atau makin sering ia akan mengulangi tingkah lakunya itu. Bwrdasarkan hasil penelitian, maka dapat dikaitkan dengan beberapa nilai yang ada dalam aktivitas perempuan pedagang makanan asongan, yaitu: 1) nilai bagi pembeli, Nilai bagi pembeli maksudnya yaitu nilai makanan yang dijual oleh perempuan pedagang makanan asongan. Dari makanan yang dijual tersebut akan berefek mengenyangkan sementara bagi pembeli. Makanan yang dijual oleh perempuan penajaj makanan asongan berupa makananmakanan kecil seperti telur asin, sala, pisang 
rebus dan lain sebagainya. 2) nilai bagi penjual, Nilai bagi penjual maksudnya adalah dari barang dagangan yang dijual, mereka Bisa mendapatkan uang yang berefek Bisa mendapatkan keuntungan atau laba dari hasil penjualan tersebut. dengan mendapatkan keuntungan, perempuan pedagang makanan asongan Bisa memenuhi kebutuhan hidup keluarganya. 3) nilai tukar lainnya, Nilai tukar lainnya yang dimaksud adalah nilai yang dilihat oleh pembeli terhadap penjual atau pedagang makanan asongan, yaitu: a) lengkap barang dagangan; Setiap pedagang makanan asongan harus lebih menyiapkan barang dagangan mereka selengkap-lengkapnya sebelum melakukan aktivitas berjualan, agar pada saat transaksi jual beli, pembeli tidak merasa kecewa dan merasa puas apabila makanan yang diinginkan dibelinya tersedia. b) kebersihan barang dagangan, Selama melakukan aktivitas berdagang, kebersihan barang dagangan harus selalu dijaga oleh perempuan pedagang makanan asongan, karena kebersihan barang dagangan akan mempengaruhi minat pembeli untuk membeli barang dagangan mereka. Kebersihan barang dagangan ini dilakukan dengan cara memisahkan makanan-makanan yang mereka jual berdasarkan jenis komoditi makanan dan dimasukkan kedalam plastik agar tidak tercemar oleh asap kendaraan yang lewat. c) kebersihan penjual, Selain faktor kebersihan barang dagangan, kebersiha penjual juga mempengaruhi pandangan dan minat pembeli dalam berbelanja pada perempuan pedagang makanan asongan. Kebersihan penjual dinilai dari segi kebersihan penampilannya. Jika penampilannya bersih, maka pembeli akan tertarik dan tidak merasa enggan untuk membeli barang dagangannya dan begitu juga sebaliknya, apabila penampilan penjual kurang bersih, maka pembeli akan berpandangan negative terhadap barang dagangan yang dijual. d) keramahan penjual, Karakter penjual juga menjadi niali bagi pembeli untuk membeli makannya. Dalam menjual makanan, penjual harus memiliki sifat ramah, sopan, dan selalu tersenyum terhadap pembeli, Waupun pembeli tersebut belum akan membeli makanan yang dijualnya.

\section{KESIMPULAN}

Berdasarkan hasil penelitian dan pembahasan tentang Aktivitas Perempuan Pedagang Makanan Asongan di Sekitar Terminal Sicincin, peneliti mengambil kesimpulan, bahwa aktivitas pedagang makanan asongan di sekitar Terminal Sicincin dapat dilihat dari segi deskripsi alokasi waktu dalam membagi pekerjaan ruamh dan pekerjaan Berdagang mereka di sekitar Terminal Sicincin, interaksi antar sesame pedagang makanan asongan, kiat penguasaan situasi pasar dan kendalakendala yang dialami oleh perempuan pedagang makanan asongan dalam pekerjaan.

\section{DAFTAR PUSTAKA}

Abdullah, Irwan. 2006. Sangkan Paran Gender. Yogyakarta: Pustaka Pelajar Offset.

Alma, Buchari dkk. 2010. Pembelajaran Studi Sosial. Bandung: alfabeta.

Amarta, Febriasista. 2012. Tindakan Pedagang Asongan Berjualan Di RSUP Dr. M. Djamil Padang.

Anogara, Pandji. 2004. Manajemen Busnis. Jakarta: PT Rineka Cipta.

Danim, Sudarwan. 2004. Ekonomi Sumber Daya Manusia. Bandung: CV Pustaka Setia.

Effendi, Candra. 2013. "Penggunaan Uang Hasil Manggaleh Oleh Lansia (Studi Kasus: Pedagang Perempuan Lanjut Usia Di Pasar Inpres Kumpulan, Kecamatan Bonjol Pasaman)."

Goode, William J. 2007. Sosiologi Kelurga. Bandung: PT Rineka Cipta.

Jelita, Rya Rekma. 2009. Fenomena Istri Berperan Ganda Terhadap Kondisi Rumah Tangga Di Kanagarian Pakan Raba' Kecamatan Koto Parik Gadang Diateh Kabupaten Solok Selatan.

Marleni. 2007. Perempuan Di Sektor Informal (Perempuan Pembuat Kue Di Cangkiang Nagari Batu Taba Kecamatan IV Angkatan Kabupaten Agam).

Mosse, Julia Cleves. 2007. Gender Dan Pembangunan. Yogyakarta: Rifka Annisa Women's Centre dan Pustaka Belajar.

Narwoko, Dwi dan Bagong Suyanto. 2011. Sosiologi Teks Pengantar Dan Terapan. Jakarta: Kencana.

Ningsih, Susanti. 2012. Potret Kehidupan 
Sosial Ekonomi Pedagang Asongan Di FISIP UNHAS.

Noor, Henry Faizal. 2007. Ekonomi Manajerial. Jakarta: PT Raja Grafindo Persada.
Sudarsono. 1988. Beberapa Faktor Pendorong Dan Penarik Anak-Anak MenjualkanMakanan Di Terminal Bus Sicincin. 
